\title{
İSLAM HUKUKU AÇISINDAN KRIPTO PARALAR VE BLOCKCHAIN ŞIFRELEME TEKNOLOJISI ${ }^{*}$
}

\author{
Dr. Hasan DOĞAN ${ }^{* *}$
}

\section{CRYPTOCURRENCIES AND BLOCKCHAIN CODING TECHNOLOGY FROM THE PERSPECTIVE OF ISLAMIC LAW}

\begin{abstract}
$\ddot{O Z Z}$
Para kavramı ihtiyaçlara ve teknolojideki gelişmelere bağlı olarak tarih boyunca değişim göstermiştir. Elektronik para kavramından sonra şimdi de kripto para kavramı küçük tasarruf sahiplerinden büyük devletlere varıncaya kadar hepimizin gündemine girmiş durumda. Kripto para kavram ve sistemi, bilişim ve ekonominin yanı sıra din ve hukuk tarafindan da irdelenmeye muhtaçtır. Kripto para sistemine peşinen taraftar veya karşı olmak yerine, borsa, bankacılık, kredi gibi kavram ve sistemlerin geçirdiği dönüşümü dikkate alarak konuya dair çok boyutlu değerlendirmeler yapılması zaruret arz etmektedir. Bu çalışmada farklı yaklaşımlar arasında karşılaştırmalarda
\end{abstract}

* Yayın Kuruluna Ulaştığı Tarih: 30.05.2018

Kabul Edildiği Tarih: 23.07.2018

DOI Numarası: $10.15337 /$ suhfd.428561

** T.C. Cumhurbaşkanlığı Özel Kalem Müdürü Büyükelçi

E-mail Adresi: hasandogan1@gmail.com

ORCID ID: 0000-0001-7810-0966 
bulunarak islam hukuku cephesinden konuya temas etmeye gayret göstereceğiz.

ANAHTAR KELIMELER: Islam hukuku, Para, Elektronik para, Dijital para, Kripto para, Blockchain, Bitcoin.

\section{ABSTRACT}

Money as a concept has changed throughout history, depending on needs and advances in technology. After electronic money, currently the concept of crypto currency has come to dominate the agenda of all, be it small savers or states. The concept and the system of crypto currency needs to be studied on the basis of not only informatics and economics, but also religion and law. Instead of supporting or opposing the crypto currency system a priori, a multidimensional assessment of the subject is needed by taking into account the evolution of concepts and systems such as stock exchange, banking and credit. This article will try to address the subject from an Islamic law perspective by comparing different approaches.

KEY WORDS: Islamic law, Money, Electronic money, Digital money, Crypto currency, Blockchain, Bitcoin.

\section{GíRiş}

Aslında geçmişi daha da eski olmakla beraber son dönemde yoğun biçimde bahse konu olan kripto para kavramının anlaşılması, ilgili bazı terim, tanım ve yaklaşımların bilinmesi ile mümkün olabilecektir. Bilhassa para kavramı ve paranın geçirdiği serüven, kripto para kavramına bakış açımızın olgunlaşmasında büyük öneme sahiptir. Çalışmamızda para, kripto para, blockchain teknolojisi kavramlarını ana hatlarıyla ele aldıktan sonra İslam hukuku ve iktisadi açıdan mevcut şartlar altında kripto paraların müspet ve menfi yönlerini vurgulamaktayız.

\section{Para Kavramı}

Para, mal ve hizmetlerin değişiminde (mübadelede) kullanılan, duruma göre saklanabilen (biriktirilebilen) ve üretilen malların, hizmetlerin kıymetini tespit eden ödeme vasıtası olarak tanımlanabilir ${ }^{1}$ Benzer biçimde devletin

1 Ludwig Von Mises, The Theory of Money and Credit, İngilizceye Çev. H. E. Batson, Yale University Press, y.y. 1953, s. 29-38; Sabri Orman, "Modern Iktisat Literatüründe Para Kredi ve Faiz", Para Faiz ve İslam, Çınar Matbaası, İstanbul 2015, s. 17; Ali Acar, "İslami 
para kavramıyla ilişkisine atıf yapan tanımlarda devletçe bastırılan, ödeme aracı olarak kullanılan, üstünde değeri yazılı kağıt ya da metal nesneye para denildiği vurgulanmaktadır. ${ }^{2}$ Bununla beraber paranın benimsenmesi hususunda bir devlet otoritesinin varlığının şart olmadığı ileri sürülmektedir. ${ }^{3}$ Bazı iktisatçılar parayı borç ödemede umumun kabul ettiği herhangi bir şey olarak tarif etmişlerdir. ${ }^{4}$ İslam tarihinde sikke, nakd (nakit), tibr (basılı, madrub olmayan para), para anlamında kullanılmıştır. ${ }^{5}$

Tanımların içinde dört unsur/ fonksiyon dikkat çekmektedir: kıymet ölçüsü, değişim vasıtası, kıymet nakli vasıtası ve ödeme vasıtası olmak. ${ }^{6}$ Buna zaman bakımından geleceği ön görme, tasarruf ve hâkimiyet aracı olma

İktisadın Esasları İsimli Kitabın Para ve Faiz İle İgili Kısımların İncelenmesi", İslam Hukuku Araştırmaları Dergisi, Sayı XVI, s. 115; Philipp Bagus, "The Quality of Money", The Quarterly Journal of Austrian Economics 12, No 4 (2009), s. 27; Stephanie LoChristina Wang, "Bitcoin is a Money", Current Policy Perspectives, Federal Reserve Bank of Boston, 14-4, s. 3; Amaresh Das, "Money as a Medium of Exchange: Then and Now: Can Technology be a Facilitator of Exchange?", Global Journal of Management and Business Research: B Economics and Commerce Volume 15, Issue 11, Version 1.0, Year 2015, s. 39.

2 Mehmet Erdoğan, Fıkıh ve Hukuk Terimleri Sözlüğü, İstanbul 2010, s. 467; Rıfat Uslu, "İslam Hukukunda Para Birimleri", İslami Araştırmalar Dergisi, 2014, XXV-I, s. 29.

3 Orman, s. 12; Leyla Ateş, "Bitcoin: Sanal Para ve Vergileme”, Vergi Sorunları Dergisi, Yıl 37, Sayı 308, Mayıs 2014, s. 132.

4 Ahmed el-Hasenî, İslam'da Para, Çeviren Adem Esen, İz Yayıncılık, İstanbul 1996, s. 24; Charles W. Evans, "Bitcoin in Islamic Banking and Finance", Journal of Islamic Banking and Finance, June 2015, Volum 3, No 1, s. 5.

5 el-Hasenî, s. 22.

6 el-Hasenî, s. 24-32; Evans, s. 5; Acar, 115-116; Mikail Altan, "Faizsiz Bankacılığın Temelleri", İslam Hukuku Araştırmaları Dergisi, Sayı XVI, 2010, s. 126. Bu fonksiyonlar mübadele ve ödeme aracı, değer ölçüsü olma şeklinde üç başlık olarak da karşımıza çıkmaktadır. Bkz. Bill Maurer, The Anthropology of Money, http://www.anthro.uci.edu/ wmmaurer/bio/Maurer-AR.pdf E.T. 20 Nisan 2018; Daniel L. Thornton, Money in a Theory of Exchange, https://files.stlouisfed.org/files/htdocs/publications/review/00/01/0001dt.pdf E.T. 20 Nisan 2018; Ali Özgüven, Iktisat Bilimine Giriş, Filiz Kitabevi, İstanbul 1989, s. 330331. Malın malla mübadelesi, trampa; malın parayla mübadelesi, satım akdi; paranın malla mübadelesi, selem; paranın parayla mübadelesi ise sarf olarak isimlendirilmektedir. Bkz. Ali Keleş, İslam’a Göre Para Kavramı, Doktora Tezi (Uludağ Üniversitesi), Bursa 1998, s. 85-86. 
fonksiyonlarının da eklenebildiği görülmektedir. ${ }^{7}$ Klasik para teorisinde paranın sahip olması gereken beş niteliğe vurguda bulunulmaktadır: taşınabilirlik, dayanıklılık, bölünebilirlik, homojenlik, taklit edilememek. ${ }^{8}$

İslam iktisat sisteminde paranın sadece üretilmiş mal ve hizmetler karşılığında ters yönde akan bir ölçme birimi olduğu belirtilmektedir. ${ }^{9}$

İslam hukukunda mal kavramı da para ile yakın ilişki içerisindedir. Malın, insanın para, eşya, hayvan ve benzeri mülk edinebildiği her şey olduğuna dair tanımı, malın parayı da kapsadığı kabulünü ortaya koymaktadır. ${ }^{10}$ Bununla beraber islam hukuku eserlerinde mal, emek ve paranın farklı bölümlerin başat unsuru olduğu dikkatten kaçmamalıdır. Mal, büyû' (alım-satım); emek, icâre (hizmet ve kira); para ise sarf (para değiş̧imi, kambiyo) bahislerinde daha çok ele alınmıştır. ${ }^{11}$

\section{Paranın Ortaya Çıkışı}

İnsanların ilk dönemlerde alış veriş münasebetleri için trampa (takas) usulünü uyguladıkları, paranın daha sonra icat edildiği bilinmektedir. ${ }^{12}$ Takas edilecek mallar arasında cins ve miktar açısından uyumsuzlukların olması, malların değer tespitinde ortaya çıkan sıkıntılar, mübadeleye konu edilmeyen ve saklanmayan belirli bir malın hesap parası olarak tayin edilmesi sonucunu

7 Özgüven, s. 330-331.

8 Osman Orhan- Seyfettin Erdoğan, Para Politikası, Avcı Ofset, İstanbul 2002, s. 5-6.

9 Sam Adian, İslam İktisat Teorisi ve Toplumsal Mekanizmalar, Hongkong 2016, s. 527.

10 Şemsüddîn es-Serahsî, el-Mebsût, Dâru'I-Ma'rife, Beyrut t.y., XIV, 2; Muvaffakuddîn Ebû Muhammed Abdullah b. Ahmed Muhammed b. Kudâme el-Makdisî (620), elMukni' fî Fıkhi'l-Imâm Ahmed b. Hanbel eş-Şeybânî, Mektebetü's-Sevâdey, Cidde 1421/ 2000, s. 151; Muhammed Emin İbn Âbidîn, Reddü'l-Muhtâr ale'd-Dürri'lMuhtâr, Dâru Âlemi'I-Kütüb, Riyad 2003, VII, 10.

Bir sözleşmede bedel yahut da satım konusu olmaları bakımından mallar üç kısımda değerlendirilmiştir.

- Alışverişte satış bedeli her halde semen olan mallar: gümüş (dirhem) ve altın (dinar) paralar.

- Alışverişte yalnız satılan (mebî’) haldeki mallar: ticaret malları / uruz (mislî olmayan hayvan, kumaş vs)

- Satılan (mebî’) de satış bedeli (semen) de olabilen mallar: ölçü- tartı ile ile alınıp satılabilen mallar. Bkz. es-Serahsî, XIV, 2.

11 Eskicioğlu, s. 43.

12 Feridun Ergin, Para Siyaseti, Hamle Mat., İstanbul 1966, s. 21-24. 
doğurmuştur. (Çin'de bıçak, Roma'da öküz, Amerika yerlilerinde hayvan derisi ve tütün gibi). ${ }^{13}$ Ancak bu malların standart niteliğe, bölünebilirlik özelliğine sahip olmaması, nevileri arasında kalite farkları bulunması, bölünme kabiliyetinin sınırlı olması, taşınma ve korunma konusunda bazı güçlükler getirmesi, insanları bir mübadele aracı olarak madenleri kullanmaya sevk etmiştir. ${ }^{14}$ Böylece bronz, demir, bakır, gümüş ve altın gibi madenler para olarak kullanılmaya başlanmıştır. Nakil, bölünme, dayanıklılık ve standart değer ifade etme bakımından ortaya koyduğu kolaylıklar, madeni paralara rağbeti artırmıştır. Başlangıçta tartı ile mübadelesi gerçekleştirilen madeni paralar, bilahare kullanımını daha kolay hale getirmek için sikke formuna sokulmuştur. ${ }^{15}$ illk paranın Anadolu veya Çin ya da Hindistan'da (Mohenjodaro kazılarında MÖ 2900 yıllarında) kullanıldığına dair farklı görüşler mevcutsa da Anadolu'da para kullanımının yaygınlığı ve Lidya Kralı Gynes'in milattan önce yedinci yüzyılda para bastırdığı tarihi bir gerçektir. ${ }^{16}$

$\mathrm{Hz}$. Peygamber (SAV) döneminde madeni para sisteminin geçerli olduğu; para basılmadığı, o dönemde tedavülde bulunan dirhem ve dinarların metal değerleri ve ticari değerlerinin eşit olduğu, bu nedenle bunların malpara sınıfına girdiği görülmektedir. Anılan dönemde Hz. Peygamber (SAV)'in yaşadığı coğrafyada Rûmî adlı tek ağırlığa sahip Bizans dinarları (altın para) ve çeşitli ağırlık ölçülerine tabi, Beğalî, (Vâfî, büyük ebatta), Taberî (küçük ebatta) adlı dirhemler (gümüş paralar) kullanıııyordu. ${ }^{17}$

$\mathrm{Hz}$. Osman ve Hz. Ali dönemlerinde üzerlerinde lafza-i celâl (Allah ismi, Lâ illahe illallahu Vahdehû Lâ Şerîke Leh, Bismillahi Rabbî gibi) ve benzeri ifadeler bulunan mahalli para basımları olmuşsa da ilk İslam parasının Abdülmelik b. Mervan tarafından bastırılmıştır. Abdülmelik b. Mervan döneminin paralarının halis altın ve gümüşten basıldığı; ağırlıklarının Hz. Ömer

13 Ergin, Para Siyaseti, s. 22.

14 Abdullah Durmuş, "Fıkhî Açıdan Günümüz Para Mübadelesi İşlemleri" (Basılmamış Doktora Tezi), Marmara Üniversitesi Sosyal Bilimler Enstitüsü, İstanbul 2008, s. 15.

15 Zehra Vildan Serin, Para Politikası, Marmara Üniversitesi Yay., İstanbul 1987, s. 27.

16 Ergin, Para Siyaseti, s. 40; Serin, s. 27.

17 Beşir Gözübenli, "islam Hukuk Literatüründe Para”, Para Faiz ve İslam, Çınar Matbaası, İstanbul 2015, s. 90 ve 93; Uslu, s. 30; Mehmet Erkal, İslam’ın Erken Döneminde Vergi Hukuku Uygulamaları, Türkiye Diyanet Vakfı Yay., Ankara 2009, s. 64.

Bu ayrım yerine, dirhem-i beğalî, dirhem-i taberî, dirhem-i mağribî ve dirhem-i yemeni şeklinde dörtlü bir tasnife de yer verilmektedir. Bkz. Uslu, s. 30. 
döneminde belirlenen miktarları esas aldığı, bir yüzlerinde (La Illahe IIllallahu Vahdehû Lâ Şerîke Leh), öteki tarafında îlas Suresinin ilk iki ayetinin yazııı olduğu bilinmektedir. Yine bu paraların bir kenarında "Muhammed Allah'ın Elçisidir" ibaresi ile Tevbe Suresi 33. ayetinin, diğer kenarında ise paraların basılış tarihlerinin kaydedildiği aktarılmaktadır. ${ }^{18}$

Madeni paralardan sonra insanlar, paraların güvenle muhafazası zaruretinden dolayı banknot olarak isimlendirilen temsili paraya yönelmişledir. Sarraflar, kendilerine emanet edilen madenler karşılığında, mal satın alımında kullanılamayan ancak sahibine emniyet, muhafaza ve nakil kolaylı̆̆ı sağlayan, önceleri nâma, sonra ise hamiline yazılı bir belge veriyorlardı. ${ }^{19}$ Bu şekilde yürüyen banknot sistemi, bir süre sonra yerini tedavülü kanunen mecbur olan ve devletin karşılık olarak altın ödeme güvencesi vermediği kağıt para sistemine bırakmıştır. ${ }^{20}$

Eski İslam ülkelerinde görüldüğü gibi Osmanlı Devleti de ilk devirlerinden itibaren kendisine ait sikke basımına başlamış, istikrarlı bir para sistemi inşa etmeye gayret göstermiş; bir finansman vasıtası olarak paradan istifade etmeye çalışmış; kendisinden evvelki İslam ülkelerinde olduğu üzere madeni paraların eşya ve yastık altı nakdi tasarruf (iddihar) olmasını arzulamamış; kıymetli madenlerin ülkeye girişini desteklemiştir. ${ }^{21}$

Paranın darbı gibi tedavülü de sınırları oldukça geniş bir ülke olan Osmanlı Devleti için zorluklar taşıdığı için devletin resmî parası (akçe) yanında, ayarlarının düşük olmaması kaydıyla, başka ülkelerin paralarının serbest dolaşımı benimsenmiştir. 1479'a kadar Osmanlı Devleti'nin altın parası olmadığı için (ilk altın para Fatih döneminde bastırılmıştır) hacmi büyük işlemlerde Venedik Dukası kullanıldığı dikkat çekmektedir. Yine aynı durumun bir tezahürü olarak ülkede var olan yabancı paraların ayar, vezin ve akçe karşısındaki kıymetleri fermanlarla halka duyurulmuştur. Ancak devletin resmî işlemlerinde resmî para olan akçe, kuruş veya kendisinin bastırdığı şahî, kızıl

18 Bilal Aybakan, "Nakit”, DiA, 2006, XXXII, 324; Uslu, s. 31.

19 Mükremin Hiç, Para, Kredi ve Fiyatlar, Atatürk Üniversitesi Basımevi, Erzurum 1971, s. 9;

20 Hiç, s. 11-13.

21 Ekrem Erdem "Osmanlı Para Sistemi ve Tağşiş Politikası: Dönemsel Bir Analiz", Bankacılar Dergisi, Sayı 56, 2006, s. 10. 
kuruş kullanılagelmiştir. ${ }^{22}$ Döneminde 36 çeşit gümüş para çeşidinin tedavülde olduğu rivayet edilen II. Mahmut'un 1808 yılında ìstanbul Altını, 1815 yılında Mahmudiye ve 1816 'da Rumi adıyla muhasebe sikkesi olarak tedavüle para süren üç önemli teşebbüsü, para birliğini sağlayamamıştır. ${ }^{23}$ 1824 yılında bastırılan Adlî isimli altın da, devletin muhasebe sikkesi haline getirilmiş, bu da yeterli olmamış, darphane ve para birliğinin temini, ancak paranın değerinin Sterlin'e bağlandığı, 1844 Para Operasyonu ile gerçekleştirilebilmiştir. ${ }^{24}$

Osmanlı'da uzunca bir dönem akçenin esas para birimi olduğu, sonra yerini kuruşa bıraktığı ve 1879 'dan sonra ise lira-kuruş dönemine girildiği görülmektedir. ${ }^{25}$ Ayrıca Osmanlı Devleti, altın ve gümüş daralması yaşadığı dönemlerde ekonomik daralma ve deflasyonla yüz yüze gelmiştir. Değerli maden arzında görülen darlık, tağşiş uygulamalarını ${ }^{26}$ ve akçedeki gümüş oranının artırılmasını (kızıl akçe) beraberinde getirmiştir. ${ }^{27}$

Öte yandan Tanzimat ile birlikte ortaya çıkan düzenlemelerden biri olarak 1840 yılında kaimeler tedavüle girmişse de, bunların banknottan ziyade faizli hazine belgesini andırdığı düşünülmektedir. Nitekim çıkarılan ilk kaimeler \% 12.5 faizli "el yazmasi" belgeler olarak 8 sene sonra itfa edilmek (ödemesi yapılmak) üzere planlanmıştır. Önceleri elle yazılan kaimelerle ilgili sahtecilik de yaygın bir durum halini almış ve kısa zamanda büyük değer kaybı yaşanmıştır. ${ }^{28} 1843$ yılından itibaren basılı kaimeler çıkarılmış, ancak halkın da güvenini yitiren kaimeler konusunda Osmanlı Devleti umduğunu elde

22 Mustafa Öztürk, "Genel Hatlarıyla Osmanlı Para Tarihi”, Türkler, Yeni Türkiye Yay., Ankara, 2002, X, 804-805.

23 İsmail Hakkı Uzunçarşılı, Osmanlı Devleti'nde Saray Teşkilatı, Türk Tarih Kurumu Basımevi Yayınları, Ankara 1945, s. 473-474.

24 Mustafa Öztürk, X, 805-806.

25 Mustafa Öztürk, X, 810; M. Özgür Yanardağ, “19. Yüzyıl Osmanlı Devleti Para Düzeni: Kâğıt Para Düzenine Geçiş Aşamalarının iktisadi Analizi”, Uluslararası Sosyal Araştırmalar Dergisi, Cilt 8, Sayı 36, 2015, s. 918-919.

26 Sikkelerin ayarlarında değişik yapılması, tashih-i sikke siyaseti; altın ve gümüş sikkelerin bakır oranının artırılması veya sikkelerin hacminin küçültülmesi uygulaması ise tağşiş siyaseti anlamına gelmektedir. Bkz. Erdem, s. 11.

27 Erdem, s. 11.

28 Yanardağ, s. 924. 
edememiş; Avrupa ülkelerinin paralarının ayarına denk gümüş mecidiyeler piyasaya sürülmüştür. ${ }^{29}$

Devlet, faizli olmalarına rağmen sürekli değersizleşen Kaime'yi piyasadan toplarken, halkın mağdur olmaması için ona en yüksek nominal değeri biçmiştir. Osmanlı Devleti'nin 22 yıllık kâğıt para serüveni de, insanları aldatan bankerler ve spekülatif kazançlarla ekonomiyi düzeltmekten çok devletin güvenine zarar veren bir hatıraya dönüşmüştür. ${ }^{30}$

\section{Para Çeşitleri ve Sistemleri}

\section{A. Para Çeşitleri}

1. Mal yahut Metal Paralar

2. Metal Parayı Tam Temsil Eden Kâğıt Paralar

3. Krediye Dayalı Paralar

Krediye dayalı paralar devlet veya bankalar tarafından çıkarılan paralar biçiminde iki ana başlık halinde ele alınmaktadır. Ufaklı para veya bunun yerine kullanılan kağıt paralar, kağıt paralar ve tedavül eden borç senetleri devlet tarafından; merkez bankaları veya özel bankaların banknotları ve bankalardaki vadesiz mevduatlar bankalar tarafından çıkarılmaktadır. ${ }^{31}$

\section{B. Para Sistemleri}

\section{Altın Standardı (Altın Tek Metal Sistemi)}

Altın dünya ekonomisinde her zaman güvenilir kıymet olarak benimsenmiştir. ${ }^{32}$ Altını esas alan bu sisteme göre (altın standardı) para arzında altın stoğu esas alınmaktadır. ${ }^{33}$ Altın tek metal sistemi geçirdiği evreler dikkate alınarak, altın sikke, altın külçe ve altın kambiyo sistemleri olarak ele alınmaktadır. ${ }^{34}$

Para biriminin belirli ayar ve ağırlıkta altından sikkeler olarak basıldığı altın sikke sistemidir.

29 Yanardağ, s. 925-926.

30 Yanardağ, s. 928-929.

31 el-Hasenî, s. 41-54; Sadun Aren, İstihdam, Para ve İktisadi Politika, Bilgi Yayınevi, Ankara 1968, s. 116-120; Orman, s. 20-23.

32 Feridun Ergin, Para ve Faiz Teorileri, Beta Yayım Dağıtım, İstanbul 1983, s. 20.

33 el-Hasenî, s. 44.

34 Orman, s. 28-29. 
Altın külçe sistemi, ilk kez 1925'te İngiltere'de ortaya çıkıp 1931'de Amerika'da sona ermiştir. Altın tedavülünü mecbur olmaktan çıkarma amacına hizmet eden, mübadelelerde kıymet ölçüsünü altın biçiminde sürdüren, ancak banknotu (temsili kağıt para) mübadele vasıtası haline getiren altın külçe sisteminde para birimi belirli ayar ve ağılıktaki altına bağı kabul edilmiştir.

Altın kambiyo sisteminde ise bir ülkedeki para birimi doğrudan altına değil, altına dönüştürülebilen başka bir ülkenin parasına bağlı kabul edilmektedir. (Bağlanan para, anahtar para, bağlı para, tâbi para olarak isimlendirilmektedir. $)^{35}$

\section{Gümüş Standartı (Gümüş Tek Metal Sistemi)}

Altının yaygınlaşmasına kadar paranın arzında gümüş madeni büyük ölçüde belirleyici olmuştur. Bu sistemde gümüş sikkelerinin ağırlığı ve ayarı devlet tarafından tespit edilirken, zamanla reel ve nominal değer arasında ciddi farklılıklar meydana gelmiştir. ${ }^{36}$

\section{Bimetalizm (Çift Metal Sistemi)}

Para standardının hem altın hem de gümüş olarak benimsendiği, diğer para birimlerinin altın ve gümüşe dönüşmesine imkan tanıyan sistemdir. ${ }^{37}$ Darphane anlayışında sınırsızlık esastır ve altın ve gümüşün değer oranı devlet tarafından belirlenmektedir. ${ }^{38}$

Gerek ayet-i kerimeler gerekse hadis-i şeriflerde nisab, alım- satım, mehir ve benzeri hususların fıkhi durum ve ölçüleri dönemin Hicaz'da kullanılan paraları ile beyan edilmiştir. ${ }^{39} \mathrm{Bu}$ noktadan hareketle $\mathrm{Hz}$. Peygamber (S)'in, döneminde var olduğu görülen çift para sistemini benimsediği, ayrıca altın ve gümüşün birbiriyle konvertibilitesine dair bir sınırlamaya gitmediği söylenebilir. Zekatta da diyette de borcun istenilen parayla ödenebilmesine imkan verilmesi bu konuda örnek gösterilmektedir. ${ }^{40}$

35 Ergin, s. 20-52; Keleş, s. 12-17.

36 el-Hasenî, s. 44; Orman, s. 33; Keleş, s. 11-12.

37 el-Hasenî, s. 45; Orman, s. 33.

38 Ergin, s. 21; Keleş, s. 20-21.

39 Gözübenli, "islam Hukuk Literatüründe Para”, s. 89; Uslu, s. 33.

40 Gözübenli, "İslam Hukuk Literatüründe Para”, s. 95. 


\section{Kağıt Para Sistemi}

Kağıt para sisteminde para, mal olma özelliğinden sıyrılarak devletin ona yüklemiş olduğu kıymet ile paralık sıfatını taşımaktadır. Buna göre altın ve gümüş miktarı dikkate alınmaksızın devletin inisyatifi ile para çıkarııı tedavüle sokulmaktadır. ${ }^{41}$

Kağıt paranın ilk kullanımı için milattan önceki ikinci yüzyılda Çin gösterilmektedir. Bununla beraber tarihte kağıt ve benzeri materyallerin paralar olarak kullanıldığına sık sık rastlanmaktadır. Uygurların "çav" adını verdikleri kağıt parayı kullanmaları bu konuda örnek olarak gösterilebilir. ${ }^{42}$ Özellikle yirminci yüzyılda kıymetli madenlerle değiştirilebilen eski formunun yerini nominal değere sahip kağıt paralar almıştır. ${ }^{43}$ Kağıt para sisteminde aslî (kağıt) para ve banka parası (kaydî para) şeklinde ikili bir yapı söz konusudur. ${ }^{44}$

Günümüzde altın standardı terk edilerek ülkelerin mal ve hizmet üretimlerine göre kıymetleri tespit edilen ve kanunun kendisine satın alma gücü tanıdığı kağıt paralar kullanılmaktadır. ${ }^{45}$

Genel olarak mal paraların, adından da anlaşıldığı gibi mal gibi tedavül ettiğini; temsili paraların bizatihi bir değerleri olmasa da altın ve gümüş karşılığında bir kıymet taşıdığını; kağıt paraların ise üstünde yazan kıymetin ötesinde maddi bir karşııkları olmadığını, gerektiğinde başka bir yerde değiştirilebilecek karşılığı bulunmadığını, sadece itibari değer ifade ettiğini; kaydî paranın ise kişiler arasında elle tutulur biçimde dolaşmayan para olduğunu söyleyebiliriz. ${ }^{46}$

\section{Elektronik (Dijital) Para Kavramı}

Elektronik para banka hesaplamalarına muhtaç olmadan işlemlerde paranın kıymetinin elektronik biçimde teknik bir cihaza depo edilmesi, ödemelerde ise "hamiline yazılı bir senet" gibi kullanılmasıdır. Ödeme veya

41 Orman, s. 37.

42 Melek Özyetgin, “Eski Türklerde Ödeme Araçları, Kağıt Para Çav'ın Kullanımı”, Modern Türklük Araştırmaları Dergisi, Cilt 1, Sayı 1, Ankara 2004, s. 100-101.

43 el-Hasenî, s. 46-50; Namık Zeki Aral, Para Meselesi ve Bretton Woods Konferansı, Alaattin Kral Matbaacılık, Ankara (t.y.), s. 7-11.

44 el-Hasenî, s. 46-47 ve 50-51; Ergin, s. 25-26.

45 Nur Keyder, Para: Teori, Politika, Uygulama, Bizim Büro Yay., Ankara 1993, s. 19.

46 el-Hasenî, s. 52; Keleş, s. 30; Osman Eskicioğlu, "İslam'da Ekonomik Sistem", İslam Hukuku Araştırmaları Dergisi, Sayı 16, 2010, s. 40. 
fon transferi bankalar arası ödeme sistemlerinde elektronik şekilde gerçekleştirilmektedir. ${ }^{47}$ Elektronik para, kâğıt paranın varlığının yanında gelişen, elektronik biçimde muhafazası ve transferi esas kabul edilen, itibari kâğıt paraların temsili görünümündedir. ${ }^{48}$ Elektronik paranın uygulama biçimleri, debit kartlar, değeri depolanmış kartlar ve elektronik nakittir. Debit kart, mevduat hesabına bağlı banka kartları, para çekilebilmesine, internette veya POS cihazlarında kredi kartı olarak ödeme yapılabilmesine imkân sağlamaktadır. Değeri depolanmış kartlarda daha önce yüklenmiş değer ile işlem yapılabilmektedir. Elektronik nakitin çok sayıda örnekleri bulunmaktadır: E-cash, CyberCash, Netcash, Mondex, GeldKarte, Proton, CASH, Netchex, Mini-Pay, Millicent gibi. ${ }^{49}$

\section{Kripto (Sanal) Para Kavramı ve Blockchain Şifreleme Teknolojisi}

\section{A. Kripto (Sanal) Para Nedir?}

Kripto para ya da sanal para, Avrupa Merkez Bankası (ECB) tarafından "Bir merkez bankası, kredi kuruluşu ya da e-para kuruluşunca ihraç edilmemiş, bazı durumlarda paraya alternatif olarak kullanılabilen bir değerin dijital temsili" şeklinde tanımlanmıştır. ${ }^{50}$ Bu tanım kripto paraların arkasında

47 Nurettin Öztürk-Asuman Koç, "Elektronik Para, Diğer Para Türleriyle Karşılaştırılması ve Olası Etkileri”, Sü iïBF Sosyal ve Ekonomik Araştırmalar Dergisi, XI, 2013, s. 212213.

48 Çarkacıoğlu, Abdurrahman (2016), Kripto-Para Bitcoin, s. 4-5. http://www.spk.gov.tr/SiteApps/Yayin/YayinGoster/1130 E.T. 25 Mayıs 2018.

${ }^{49}$ Armağan Ebru Bozkurt Yüksel, "Elektronik Para, Sanal Para, Bitcoin ve Linden Doları’na Hukuki Bir Bakış", İstanbul Üniversitesi Hukuk Fakültesi Mecmuası, Cilt 73, Sayı 2, İstanbul 2015, s. 190.

50 European Central Bank, Virtual Currency Schemes - A Further Analysis, Frankfurt 2015,

https://www.ecb.europa.eu/pub/pdf/other/virtualcurrencyschemesen.pdf adresinden 20 Mayıs 2018' de erişildi.

Türkiye'de elektronik paranın tanımı: "elektronik para ihraç eden kuruluş tarafından kabul edilen fon karşılığı ihraç edilen, elektronik olarak saklanan, bu Kanun'da tanımlanan ödeme işlemlerini gerçekleştirmek için kullanılan ve elektronik para ihraç eden kuruluş dışındaki gerçek ve tüzel kişiler tarafından da ödeme aracı olarak kabul edilen parasal değer" şeklindedir. Bkz. 6493 Sayılı Ödeme ve Menkul Kıymet Mutabakat Sistemleri, Ödeme Hizmetleri ve Elektronik Para Kuruluşları Hakkında Kanun, Madde 3. 
herhangi bir devlet ya da resmi otorite bulunmasına dair bir zaruretin ön görülmediğine işaret etmektedir.

Sanal para ve elektronik para sık sık karıştırılan, ancak anlamları farklı kavramlardır. Elektronik para, bilgisayar veya bir başka veri depolama vasıtasında kişilerin adına ve bilhassa internet üzerinden yapılan işlemlerde kullanılan ödeme vasıtasıdır. Sanal paraysa fiziki bir varlığından söz edemeyeceğimiz, somut biçimde elimize alamayacağımız, elektronik ticari işlemlerde kullanılabilen, ancak kendisine mahsus hesap birimine dayanan ödeme vasıtasıdır. Elektronik para, piyasada bilinen Euro, Dolar, Türk Lirası gibi para birimleri iken, Bitcoin'de olduğu gibi sanal paranın para birimleri böyle değildir. Zira sanal paranın üreticisi, sanal paranın birimini de tespit etmektedir.

Sanal para birimleri, herkesçe kabul edilen eletronik para birimlerinden farklı olarak sanal bir topluluk içinde benimsenmektedir. Elektronik ve sanal paralar, yasal düzenleme açısından da farklılık arz etmektedir. Elektronik parayı elektronik para kuruluşları tedavüle sokarken, sanal para özel kişiler tarafından da piyasaya sürülebilmektedir. Elektronik paranın arzı sanal paradan farklı olarak sabittir. Denetim, itibari değerinin garanti altında olması bakımından da sanal para ve elektronik parada farklı zeminler söz konusudur. Bu farklılıklara rağmen dijitallik ortak paydası altında sanal paranın bir çeşit elektronik para olduğunu söyleyebiliriz. ${ }^{51}$

\section{B. Blockchain Teknolojisi}

Para ve finans sistemleri dışında merkezi kaydı gerektiren pek çok alanda kullanımı mümkün olan, bir varlığı ıslak imzasız ve elden ele geçirmeden güvenli şekilde muhafaza ve transfer etmeyi sağlayan, kendi kendini denetleyebilen bir dijital değer ekosistemidir.

Kimileri bu sistemi dijital defteri kebir olarak isimlendirmekteyse de defteri kebirdeki gibi tek bir merkezi kayıt (server vs) değil, sistemi kullanan tüm üyelerde kayıtların tamamı blok zincirler halinde mevcuttur ve bu da tahrifata karşı önemli bir güvence olarak görülmektedir.

Blockchain (blok zincir), işlemlerin şifrelenmiş olarak izlendiği dağıtık bir veri tabanıdır. Blockchain teknolojisi, her bir kullanıcıya atanmış (şifre gibi gizli tutulan) özel bir anahtar ve diğer tüm kullanıcılarla paylaşılan genel bir

51 Yüksel, s. 198. 
anahtar kullanılmak suretiyle herkese açık bir anahtar şifreleme tekniği yardımıyla iki kez harcama sorununu ortadan kaldırmaktadır.

Işlem, sanal parayı alacak olanın kendi genel anahtarını paranın mevcut sahibine göndermesiyle başlar. Para bir algoritmanın dijital imzasıyla transfer edilir. Genel anahtarlar, blok zincirde saklanan şifrelenerek üretilmiş adreslerdir. Her para bir adres ile ilişkilendirilir ve şifreli ekonomide her bir işlem, basitçe sanal paranın bir adresten diğerine değiş-tokuşudur. İşlemler izlenebilir olmasına rağmen, işlemi yapan kişilerin kimliğinin bilinmemesi sağlanmaktadır. ${ }^{52}$

\section{Kripto Para Çeşitleri}

"Blockchain" şifreleme teknolojisi ile üretilmiş çok sayıda para birimi bulunmakla beraber, ilk olması ve yaygınlığı ile "Bitcoin" ön plana çıkmıştır. Bitcoin dışında Ethereum, Ripple, Bitcoin Cash, Cardano, Litecoin, Nem, Neo, Stellar, IOTA, EOS, Monero gibi farklı adlar altında ve sayısı her gün değişen, makalemizin son güncellendiği tarih itibarıyla 1348 farklı kripto para işlem görmektedir.

30 Haziran 2018 tarihi itibariyle kripto paraların toplam piyasa değeri 257,78 milyar ABD doları ve günlük işlem hacmi 10 milyar $A B D$ doları civarındadır. Bitcoin bu piyasanın yaklaşık \%43'ünü oluşturmakta olup, yaklaşık 109 milyar ABD doları piyasa değerine ve günlük 5 milyar $A B D$ doları işlem hacmine sahiptir. ${ }^{53}$

\section{Bitcoin}

Bitcoin, bir kullanıcıdan diğerine doğrudan iletilmesi mümkün olan (peer to peer, eşlerarası) bir sanal paradır. ${ }^{54}$ Şifre para kavramı ise paranın yapım ve iletiminin kriptoloji (cryptography, şifre bilimi) ile ve merkezi bir otoriteye ihtiyaç duymaksızın gerçekleştirilebileceğine dayanan sistemi ifade etmektedir. Bu çerçevede bitcoinin de içinde bulunduğu kripto paraların, elektronik ve dijital para kavramlarıyla birebir örtüşmediğini söyleyebiliriz. ${ }^{55}$

52 Marc Pilkington, Blockchain Technology: Principles and Applications, Research Handbook on Digital Transformations, 2016, s. 5; Burçin Bozdoğanoğlu, "Sanal Para Birimi Bitcoin'in Kayıtdışı Ekonomi ile Karapara Faaliyetlerine Etkisi ve Vergilendirilmesi", Mali Hukuk Dergisi, Cilt 10, Sayı 111, Mart 2014, s. 8.

53 https://coinmarketcap.com/ (E.T. 30 Haziran 2018)

54 Ateş, s. 133; Bozdoğanoğlu, s. 4.

55 Ateş, s. 133 ve 134. 
İtibari para sistemine alternatif olarak geliştirilen yeni bir dijital para sistemi olan $^{56}$ Bitcoin'in ilk temellerine dair çok sayıda iddia bulunmakla beraber $^{57} 2009$ yılında gerçek kimliği bilinmeyen Satoshi Nakamoto adını kullanan bir kişi ya da grup tarafından internette yayımlanan bir çalışma "Bitcoin: Eşler Arası Elektronik Nakit Sistem, Kasım 2008" ile Bitcoin ilk kez tanıtılmış ve kullanıma açılmıştır. ${ }^{58}$ Bitcoin, belki en şöhretlisi olabilir ama ilk sanal para değildir. David Chaum tarafından üretilen ilk sanal paralardan DigiCash 1990'lı yıllarda ekonomi dünyasında boy göstermiş, 1998 yılında bir iflas hikayesiyle de ortadan kalkmıştır. Bitcoin, sanal paranın bir alttürü olarak şifre paranın (crypto currency) ilk örneği olarak nitelenebilir. ${ }^{59}$

Illk bitcoin bloku Nakamoto tarafından üretilmiştir. Toplam Bitcoin sayısı 21 milyon adet ile sınırlı olarak belirlenmiş olup, halen 17,1 milyon adedi kullanımdadır. ${ }^{60}$ Kalan miktardan her bir Bitcoin'in kullanıma girebilmesi için yapılan işlemlerin doğrulamasını sağlayan bir matematiksel problemin bilgisayarların işlemci gücünden yararlanarak çözülmesi gerekmektedir. Bu şifreyi çözen kişiler sisteme katkı sağlamakta ve 12,5 Bitcoin ile ödüllendirilmektedir. Bu işleme "Bitcoin madenciliği" denilmektedir. Bu yöntem Bitcoin arzının kontrolsüz gerçeklememesi için kurgulanmıştır. Bu şifreyi çözmek oldukça profesyonel bilgi ve çok güçlü teknik sistemsel donanım gerektirdiğinden sıradan bir kişinin yapabileceği bir iş değildir. Bu nedenle, Bitcoin kullanmak isteyen kişiler, internette kripto para satışı yapan sitelerden geleneksel para birimleri karşılığında sanal para satın alabilmektedir. Internet üzerindeki bu kripto para borsalarında oluşan talebe bağlı olarak Bitcoin'in ulusal para birimleri karşısındaki fiyatı anlık olarak oluşmaktadır.

Bitcoin almak veya işlem yapmak için Bitcoin Protokolü adı verilen istemcinin (bitcoin client) bilgisayarda çalıştııılması veya bu istemciyi çalıştıran bir web sitesinde hesap açılması gerekmektedir. ${ }^{61}$

56 Çarkacıoğlu, s. 11-14.

57 Örneğin 9 Ocak 1988 Sayılı The Economist Dergisi. Ayrıca 1998 yılında Wei Dai tarafından ortaya atılan fikrin bir mahsulü olduğu savunulmaktadır. (Bkz. Ateş, s. 133)

58 Satoshi Nakamoto, Bitcoin: A Peer-to-Peer Electronic Cash System, http://www.bitcoin.org/bitcoin.pdf

59 Ateş, s. 132 ve 133.

60 https://coinmarketcap.com/currencies/bitcoin/ E.T. 30 Haziran 2018

61 Ateş, s. 134. 


\section{Kripto Paraların Meşruiyeti Sorunu}

\section{A. Aleyhte İleri Sürülen Görüşler}

Kripto paraların meşruiyeti hususunda olumsuz kanaate sahip olanların değerlendirmelerini şöyle sıralayabiliriz. Öncelikle kripto paralar, devlet veya genel otorite güvencesi yoksunluğu nedeniyle ciddi eleştirilere maruz kalmaktadır. Bu iddiaya göre kripto paralar, para politikası aracı olarak da kullanılamamaktadır. ${ }^{62}$

Erişim tahdidi de, bu paranın dezavantajlı yönlerinden biridir. Internete erişim olmayan bir noktadan veya mevcut internet imkanının bir şekilde ortadan kalkması halinde kullanıcı ile hesabı/ kripto parası arasındaki ilişki kopmaktadır. Kripto hesaptan gerçekleştirilen işlemlerin geri alınamaması, hesabın kaybolma riskleri kripto paralar hakkında ciddi itimat sorunlarıdır. Bu çerçevede kripto paraların saklandığı ana bilgisayarların sabit disklerinin beklenmedik biçimde bozulması ve veri kaybı yaşaması; virüs ve benzeri saldırılara maruz kalması da hukuki ve teknik problemler olarak karşımızda durmaktadır. ${ }^{63}$

Kripto paralarla ilgili olarak suç gelirlerinin, kara paranın aklanması ve terörizmin finansmanı gibi konularda düzenleme gerektiren geniş bir tartışma alanı bulunmaktadır. Özellikle de işlemlerin gerçek kimliklerle değil dijital sanal kimliklerle yapılıyor olması, büyük bir tehdit oluşturmaktadır. ${ }^{64} \mathrm{Bu}$ çerçevede dünyada ve ülkemizde kripto paralara artan rağbet karşısında ilgili otoriteler çeşitli çalışmalar yürütmektedir. Bunların yasal zemine oturtulması, denetlenmesi, ülkelerin tek başına kontrol mekanizmaları oluşturması ya da yasaklamalar şu an için zor görünmektedir. Gelinen noktada birçok ülkede denetleyici ve düzenleyici kurumlar, kripto paraların barındırdığı risklere yönelik uyarı yayımlamıştır. ${ }^{65}$ Kripto para sistemi merkezciliği peşinen reddettiği için el koymaya veya taraflar arasında transferi engellemeye müsait

62 Bozdoğanoğlu, s. 6; Mufti Faraz Adam (2017), Bitcoin: Shariah Compliant? s. 45-46. https://afinanceorg.files.wordpress.com/2017/08/research-paper-on-bitcoin-muftifaraz-adam.pdf E.T. 25 Mayıs 2018

63 Ege, s. 26.

64 Bozdoğanoğlu, s. 5 ve 8.

65 Bozdoğanoğlu, s. 5. 
değildir. ${ }^{66}$ Bu durum ilk bakışta cazip gibi görünse de kamu düzen ve güvenliği, ayrıca uluslararası suçla mücadelede büyük bir boşluğa neden olmaktadır.

Güçlü bir şifreleme teknolojisi ile oluşturulan, internet ortamında kullanılan sanal paraların değeri, bir değişim aracı olarak yaygın kabul görmesinden ya da bir emtia gibi algılanmasından kaynaklanmaktadır. Kripto paraların değeri de geleneksel para birimleri ve emtia gibi arz ve talebe göre işlem gördüğü piyasalarda oluşmaktadır. Bugün gelinen noktada kripto para birimleri, değişim aracı olarak kullanı Imanın ötesinde spekülatif yatırım amaçı talep görmektedir. Bu nedenle bu paraların fiyatları yüksek düzeyde oynaklık göstermektedir. Anılan durum da özellikle kullanıcıların (tüketicilerin) korunması problemini ortaya çıkarmaktadır.

Kripto paraların meşruiyeti i̇slam hukukçuları tarafından da sorgulanmaktadır. Esasen bu konuda kullanıcılar arasında mübadele ve bir değer tespit aracı olarak güven veren paraların kullanımının caiz olduğu açıktır. ${ }^{67}$ Ancak İslam hukukçularının bir kısmı kripto paraları (ki bilhassa bahsi geçen Bitcon'i) bir mal olarak görmeyip, alınıp satılabilen bir şey kabul etmemekte ve İslam hukukunun meşru görmediği kurgusal bir yatırım olduğunu ileri sürmektedir. ${ }^{68}$ Her şeyden önce kripto paraların maddi anlamda alınıp satılmaması, mülkiyete konu olması bakımından büyük problem teşkil etmektedir. Kripto paraların somut bir servete veya mülkiyete dayanmamasından hareketle fonksiyonu ve yararı baştan tartışmalı görülmektedir. ${ }^{69}$ Bu görüşteki i̇slam hukukçuları, bir mübadele aracı olarak kripto paraların üretim biçimi, tedavüle çıkış aşaması ve muhataplık niteliğinde garar $^{70}$ ve bir aldatma aracı olarak kullanılabilmesine imkan tanıyan

66 Ateş, s. 134.

67 Din İşleri Yüksek Kurulu Kararı, https://kurul.diyanet.gov.tr/Karar-MutalaaCevap/38212/dijital-kripto-paralarin-kullaniminin-dini-hukmu-nedir-

68 Adam, s. 40.

69 Adam, s. 41.

70 Garar, ciddi anlamda belirsizlik ifade etmektedir. Bkz. İbn Rüşd, II, 142.

Ebu Hureyre, Hz. Peygamber (SAV)'in garar ve hasâ alışverişinden nehyettiğini haber vermektedir. Bkz. Süleymân b. Eş'âs Ebû Dâvûd, Sunen, Dâru Sahnûn-Çağrı Yayınları, İstanbul 1992, (Kitâbu'l-Buyû' ve'l-i̇cârât), III, 672; Ebû Îsâ Muhammed b. Îsâ b. Sevra et-Tirmizî, Sunen, Dâru Sahnûn-Çağrı Yayınları, İstanbul 1992, (Kitâbu'I-Buyû'), III, 532; Ebû Abdullah Muhammed b. Yezîd b. Mâce, Sunen, Dâru Sahnûn-Çağrı Yayınları, İstanbul 1992, (Kitâbu't-Ticârât), II, 739. 
yapısının altını çizmektedir. Bununla beraber kripto paraların haksız ve sebepsiz zenginleşmeye alet olabileceğine dikkat çekilmektedir. ${ }^{71}$

İslam hukukçuları, spekülasyonlara açık kripto paralardaki ani yükseliş ve düşüşlerin meydana getirdiği güvensizlik ve mağduriyeti de gündeme getirmektedir. Tedavüle süreni, kurucusu, sorumlusu, merkezi, hatta sistemin kendisi belli olmayan, denetimsiz kripto paraların kontrolsüz biçimde suçlara alet olabileceği, uyuşturucu, silah vs. tüccarlarına imkanlar sağlayabileceği savunulmaktadır. ${ }^{72}$

İslam hukukunda verginin esas sebebi üretimdir ve vergilendirme sistemi hassastır. ${ }^{73}$ Bu çerçevede kripto paraların vergilendirilmesi büyük güçlükler taşımaktadır. ${ }^{74}$ Kripto paralar, vergi cenneti ibaresinin altında yatan iki vasfı, vergiye tabi olmama ve anonimliği ihtiva etmektedir. Belli bir cüzdan ve anahtar çiftinin kontrolü altındaki kripto paraların kime ait olduğunun tespiti imkansızdır. ${ }^{75}$ Bu da devletler için büyük bir vergi kaybı sorununu ortaya çıkarmaktadır.

Döviz alım satımı gibi yöntemlerle para kazanmak meşru ise de stokçuluk (kenz) kapsamında değerlendirilebilecek biriktirmenin burada da geçerli olduğu; üretime katılmayan paranın topluma yarar sağlamayacağı ve takva sahibi Müslümanların tercih etmemeleri gereken bir kazanç yolu olduğu dile getirilmektedir. ${ }^{76}$

Kripto paralarla ilgili olarak, piyasa dengesi ve emek anlayışına zarar vermesi, kripto para kullanıcılarının hukuki korumadan yoksun bulunması, ilgili

71 Din işleri Yüksek Kurulu'nun konuya ilişkin fetvası için bkz. https://kurul.diyanet.gov.tr/Karar-Mutalaa-Cevap/38212/dijital-kripto-paralarinkullaniminin-dini-hukmu-nedir- E.T. 23 Mayıs 2018

72 Karaman, "Sanal para bitcoin, bara)" https://www.yenisafak.com/yazarlar/hayrettinkaraman/sanal-para-bitcoin-bitpara2041314 E.T. 15 Mayıs 2018.

73 Eskicioğlu, s. 44

74 Hayrettin Karaman'ın konuya dair değerlendirmesi için bkz. Hayrettin Karaman, "Sanal para (bitcoin, bitpara)" https://www.yenisafak.com/yazarlar/hayrettinkaraman/sanal-para-bitcoin-bitpara2041314 E.T. 15 Mayıs 2018

75 Ateş, s. 138.

76 Karaman, https://www.yenisafak.com/yazarlar/hayrettinkaraman/sanal-parabitcoin-bitpara-2041314 
mercilerin etkisiz bırakılması; ölçü, değer ve bozma işlemlerinde hile, kandırma ve aldatmaya açık olması gibi nedenler de ayrıca zikredilmekte, bu hususta da "Bizi aldatan bizden değildir"77 hadis-i şerifine atıfta bulunulmaktadır. ${ }^{78}$ Kripto paraların kullanımının gerek bireyler gerekse devletlere yönelik büyük tehlikeler taşıdığı; bunun da "zarar vermek ve zarara zararla karşılık vermek caiz değildir" ${ }^{\prime 79}$ hadis-i şerifi/hukuk ilkesine de aykırı bir durum oluşturduğu ifade edilmektedir. ${ }^{80}$

Kripto paraların kanuni değer taşımadığı, para olduğuna dair ciddi şüpheler bulunduğu; içerdiği risklerin, sebep ve amaçlarını çürüttüğü; varlığı gözetmeye dair makâsıd-ı şerîaya uygun düşmediği savunulmaktadır. Aynı görüş mensuplarına göre ayrıca kripto paraların bir mübadele aracı olarak kullanılmasına meşruiyet ışığı yakacak bir örf de bulunmamaktadır. ${ }^{81}$

Kripto paralar ciddi riskler taşımaktadır: güvenlik, teknolojik, kara para, kaybolma, data ve işlem, arabulucu, mevzuat, yapısal deflasyon, rekabet, ölçülebilirlik, tekel ve likidite riskleri gibi. Bu da kripto paraların tedavülde, şeffaflıkta, malın korunması ve adalet sisteminde makasıd-ı şerîa'ya uyumlu olduğuna dair bir görüntü arz etmemektedir. ${ }^{82}$ Bütün bu gerekçe ve tespitlerden hareketle İslami finansın hedeflerine uymayan, reel ekonomiye, mal-hizmet üretimi ve istihdama katkıda bulunmayan, ${ }^{83}$ saadet zinciri gibi bir manzaranın ortaya çıkmasına sebebiyet veren, bazı insanların mağduriyetlerine, bazı insanların haksız ve sebepsiz zenginleşmesine yol açan dijital kripto (sanal) paraların kullanımına, alınıp satılmasından kazanç sağlamaya cevaz verilmemekte, meşruiyet tanınmamaktadır. ${ }^{84}$

77 Ebû'l-Huseyn b. el-Haccâc Müslim, el-Câmiu's-Sahîh, Dâru Sahnûn-Çağrı Yay., İstanbul 1992, (Kitâbu'l-Îmân) I, 99.

78 Mısır Başmüftüsü Şevki İbrahim Allâm'ın fetvası için bkz. http://www.daralifta.org/ar/ViewFatwa.aspx?sec=fatwa\&ID=14139 E.T. 25 Mayıs 2018

79 Ebû Abdullah M3alik b. Enes el-Asbahî el-Himyerî, el-Muvatta', Dâru Sahnûn-Çağrı Yayınları, İstanbul 1413/1992. (Kitâbu'l-Akdiye), II, 745. Ayrıca Mecelle-i Ahkâm-ı Adliyye, Madde 19.

80 Allâm, http://www.dar-alifta.org/ar/ViewFatwa.aspx?sec=fatwa\&ID=14139

81 Adam, s. 42-43.

82 Adam, s. 49.

83 Adam, s. 44.

84 Din İşleri Yüksek Kurulu, https://kurul.diyanet.gov.tr/Karar-MutalaaCevap/38212/dijital-kripto-paralarin-kullaniminin-dini-hukmu-nedir- ; Karaman, 


\section{B. Lehte Ortaya Konan Fikirler}

Kripto paraya dair lehte yaklaşım sergileyenlerin görüşlerini şöyle özetleyebiliriz. Kripto para sisteminde kullanıcılar, sistemin idamesinden yararlanarak aksaklıklardan ortak biçimde etkilenmektedir. Buna göre faydarisk paylaşımı söz konusudur ve kullanıcılar arasında gevşek yapılı bir ortaklık sistemi olduğu belirtilebilir. ${ }^{85}$

Kripto paralar, zaman (günün herhangi bir saatinde, tatillerden bağımsız) ve mekâna bağlı olmaksızın, çok yüksek hızda, anlık biçimde işlem ve transferlere imkân tanıması; mevcut bankacılık sisteminden daha karmaşık, güvenli ve taklit edilemez bir altyapı vadetmesi; kullanıcılarını internetin bulunduğu her noktadan erişim imkanı sağlaması, kişisel ve özel bilgilerin verilmesine ihtiyaç duymaması, işlemlerde herhangi bir alt ve üst sınır getirmemesi ve ekstra masraf ve ödeme gerektirmemesi gibi vasıflarıyla önemli avantajlar sunmaktadır. Devletlerin kontrolündeki para ve hesaplara göre el konulması daha güç, hatta mümkün olmayan bir statü ortaya koymaktadır. ${ }^{86}$

Döviz, altın ve benzerlerine para yatırmak ve fiyatları arttığında bunları satmak ve böylece para kazanmak zaten caiz görülmüştür. ${ }^{87}$ Kripto paralar da döviz, altın ve benzeri helal yatırım araçlarının tümü gibi spekülasyona açıktır ve bu durum da anılan sistemi haram olarak nitelemek hususunda temel ölçü biçiminde değerlendirilemez.

Kripto paraların devlet gibi muteber bir otorite tarafından tedavüle sokulmamasından dolayı meşru olmadığı iddiasına karşı, bir nesnenin para olarak kabulünde devletçe basılma zorunluluğunun bulunmadığı, önemli olanın halkın kabul ve kullanımı olduğu günümüz iktisatçılarınca vurgulanmaktadır. ${ }^{88}$ Bununla beraber kripto paraların bazılarının doğrudan

https://www.yenisafak.com/yazarlar/hayrettinkaraman/sanal-para-bitcoin-bitpara-

$2041314 \quad$; Allâm,

http://www.dar-

alifta.org/ar/ViewFatwa.aspx?sec=fatwa\&ID=14139

85 Evans, S. 8.

86 Ateş, s. 134; Börteçin Ege, "Sanal Dünyanın Gerçek Parası: Bitcoin", Bilim ve Teknik, Kasım 2013 Sayısı, s.25.

87 Karaman, https://www.yenisafak.com/yazarlar/hayrettinkaraman/sanal-parabitcoin-bitpara-2041314

88 Ateş, s. 132. 
devletler tarafından tedavüle sokulduğu da bilinmektedir. ${ }^{89}$ Dolayısıyla üzerinde belirsizlik bulunduğu ileri sürülemeyen, hem de bir devlet veya bir muteber otoritenin teminatını tekeffül ettiği kripto bir paranın kullanımı, tabii olarak meşruiyet zemini yakalayacaktır.

Kripto paraların karşılığının olmamasına dayalı gayri meşruluk iddiaları da bu paraların kullanımının haram olduğu iddiası için geçerli bir delil görüntüsü sunmamaktadır. Nitekim kâğıt paralar, itibari değer ifade eder ve dünyadaki para birimlerinin kaçının ne kadar karşılığının olduğu, hatta bazılarının karşılı̆ının olup olmadığı da bilinmemektedir. Ayrıca bugün merkez bankalarının para basmalarının limitinin olmadığı, bu durumun pek çok ülkede hiper enflasyona neden olduğu görülmektedir. ${ }^{90}$

Kabzın bulunmaması, kripto paraların caiz olmadığı konusunda ortaya atılan bir başka meşruiyet sorunu olarak dikkat çekmektedir. Ancak İslam hukukunda kabz, hakiki ve hükmi olarak iki kısımda değerlendirilmektedir. Buna göre menkullerin teslimi için mutlak surette yerlerinin değiştirilmesinin bir zaruret olmadığı, satıcı için tahliyenin de kâfi olduğu belirtilmektedir. ${ }^{91} \mathrm{Bu}$ durumla paralellik arz eden, zilyetliğin hükmen teslimi esas olan ve özellikle günümüzde tüm aşamalarının sanal ortamda, kendine ait usullerle gerçekleştiği, garar riski bulunmayan hususlarda (havale gibi) kabz şartı aranmamaktadır. ${ }^{92}$ Anılan çerçevede bu neden de kripto paraların aleyhine bir delil olarak ileri sürülemez.

Vergilendirme konusundaki belirsizliklerin bulunması kripto paralar için dile getirilen bir başka gayri meşruluk sebebidir. Şu kadarı var ki, her tasarruf enstrümanında vergi kaçırılması teorik olarak mümkündür. İyi niyet ölçüsünün varlığı nispetinde vergi de hakkaniyetle tahakkuk edecektir. Şeffaflık, kayıt sistemi ve denetim noktasında avantajları bulunmakla beraber kripto paraların, diğer paralara oranla vergi kaçırmaya daha müsait olduğu da kabul edilmelidir. Ancak vergi kaçırma riskinin yüksek olması, bu para sisteminin haram olarak nitelendirilmesi hususunda yeterli sebep değildir. Bu riskin ortadan kaldırımasının yolu da konuya dair hukuki düzenlemelerin

89 Ethrium, Rusya ve son olarak Petro, Venezuela tarafından tedavüle sokulmuş kripto paralardır.

90 Evans, s. 7.

91 Mustafa Kisbet, "İslam Hukukuna Göre Satılan Malın Kabzı ve Hükümleri”, İslam Hukuku Araştırmaları Dergisi, Sayı XVI, 2010, s. 483.

92 Kisbet, s. 484 ve 490. 
yapılmasından geçmektedir. Nitekim Çin ve Brezilya gibi ülkeler bu konuda ciddi adımlar atmış ülkeler olarak karşımızda durmaktadı ${ }^{93}$ ve kripto para konusunda çok sayıda ülkede yasal düzenleme yapıldığı bilinmektedir. ${ }^{94}$

Kripto paranın lehinde görüş beyanında bulunan bazı İslam hukukçuları, kripto paranın temelinde yer alan madencilik işlemi ile cuâle (ciâle veya ceâle) akdi arasında benzerlik ileri sürmektedir. ${ }^{95}$ Cuâle gerçekleştirilecek bir işe karşı ücret, ödül taahhüdü ve vaadini ifade etmektedir. Cuâle akdi konusunda Hanefiler ve Zâhirîler dışındaki mezheplerin müspet yaklaşımı söz konusudur. ${ }^{96}$ Cuâle akdine istisnai durumlar dışında sıcak bakmayan, cuâlenin var ile yok arasında bir şey için yapılması nedeniyle riske dayanan bir edinme durumu söz konusu olduğunu; baştan somut bir mal veya emek bulunmadığını ve akit taraflarından birinin belirsizliğini gerekçe gösteren Hanefiler ve Zâhirîlere karşı diğer mezhepler cuâleyi meşru bir akit olarak ele almaktadır. ${ }^{97}$ Madencilik de, aslında yapanın karşılığında mükâfat elde ettiği belirli bir eylemdir ve bu da süren mali işlemlerin elektronik para ağına çok kısa süre içinde kaydedilmesidir. Bahsi geçen işlem bu açıdan bir tür cuâle akdi gibi kabul edilebilir. ${ }^{98}$ Nitekim cuâle, mubah olmak kaydıyla işverenin istediği bir işin, meçhul (her özelliği net olmayan) olsa dahi yapılması veya ona bir süreliğine hizmet edilmesi karşılığında işverenin belirlediği ücrettir. Bu tanım ile madencilik işlemi bir yakınlık görmek mümkündür. Örneğin elektronik para

93 Ateş, s. 133.

94 Bozdoğanoğlu, s. 7-8.

95 Abdullah b. Muhammed b. Abdülvehhab el-Akîl, el-Ahkâmu'l-Fıkhiyyetü'l-Muteallika bi'l-Amelâti'l-Elektruniyye, el-Memleketu'l-Arabiyyetü's-Suûdiyye Vezâretü't-Ta'lîm el-Câmiatü'l-İslâmiyye bi'l-Medîneti'l-Münevvere, s. 41 http://iefpedia.com/arab/wpcontent/uploads/2018/01/Bitcoin4.pdf E.T. 25 Mayıs 2018

96 ibn Kudâme, s. 232; Şemsüddîn eş-Şeyh Muhammed Arafe ed-Dessûkî, Hâşiyetü'dDessûkîalâ Şerhi'I-Kebîr, Îsâ el-Bâbî el-Halebî ve Şürakâuh, t.y.y.y., IV, 60-61; Ebû İshâk İbrâhim b. Ali b. Yûsuf eş-Şîrâzî, el-Mühezzeb fî Fıkhi'l-Imam eş-Şâfiî, Dârü'l-Ma'rife, Beyrut 2003, II, 437; Ebû Ca'fer Muhammed b. el-Hasen b. Ali et-Tûsî, el-Mebsût fî Fıkhi'I-İmâmiyye, el-Mektebetü'l-Murtadaviyye, Tahran t.y., II, 367; Hocaefendizade Ali Haydar Efendi, Dureru'l-Hukkâm Şerhu Mecelleti'l-Ahkâm, Dâru Alemi'l-Kütüb, Beyrut 2003, I, 502.

97 el-Akîl, s. 42-43; Şevki Ahmed Dünya, el-Cuâle ve'l-Istısnâ', el-Benku'l-i̇slâmî li'tTenmiye el-Ma'hedü'l-İslâmi li'l-Buhûs ve't-Tedrîb, t.y. y.y., s. 7-8; Mehmet Âkif Aydın, "Cuâle" Maddesi, TDV İslam Ansiklopedisi, VIII, 77-78.

98 el-Akîl, s. 41. 
ağı "Bitcoin"in madencilik yapana belirlediği 50 Coin, ortaya konulan belli bir ücrettir ve her dört yılda bir \% 50 oranında düşmektedir. Buna göre câil (işveren) işi ilk önce yapana belli miktarda coin veren Elektronik Para Ağı Bitcoin iken; tanımda konu edilen mubah iş, işlemlerin çok kısa süre içinde elektronik para ile belgelenmesi durumudur. Bu da mahiyeti de süresi de belli bir iştir. ${ }^{99}$ Mudarebe benzeri insanların ihtiyacına binaen başvurdukları bir yoldur. ${ }^{100}$ Buna göre işverenin belirleme yapmadığı bir tür cuâle akdi olarak görülebilecek madencilik ve bu süreçte gerçekleştirilen ortaklık, caizdir ve madencinin işi tamamladıktan sonra belirlenen bedeli alma hakkı vardır. ${ }^{101}$

Kripto paralar piyasalardaki tekel paraların hâkimiyetini tehdit etmekte; -eğer bu alanda da bir tekelleşme yaşanmazsa- para işlem ve transferlerinde yeni bir alternatif sistemi haber vermektedir. Kripto para sistemi, bankacllık sistemini zamanla kısıtlayacak ve belki kısmen de olsa tasfiye etme cüretini gösterebilecek bir gelecek beklentisi ortaya çıkarmaktadır. Kripto para sisteminde bankacılığın standart aracılığı ortadan kalkmaktadır. ${ }^{102}$

Bütün bunların dışında belki de en önemlisi kripto para sisteminde -en azından şu anki koşullarda- faiz uygulaması bulunmamaktadır. ${ }^{103}$ Faizin İslam ekonomik sisteminin en önemli kırmızı çizgisi olduğu dikkate alındığında, bu durum, kripto paraların meşruiyeti için en önemli belirleyici özelliği haline gelmektedir.

İslam hukukçularının kripto paralara dair lehte yaklaşımı iki farklı biçimde tezahür etmektedir. Bazı İslam hukukçuları kripto paraların (özellikle bitcoin'i kastederek) bir dijital sermaye olduğunu kabul edip para vasıflarını taşımadığını savunmaktadır. Diğer bazıları ise kripto paraların dijital bir sermaye olması yanında para olarak da meşruiyetini tanımaktadır. ${ }^{104}$

Kripto paraları mal olarak benimseyen İslam hukukçuları, bu yatırımı ekonomik değerinden kaynaklanan ve aynı zamanda depolanabilir, geri alınabilir bir varlık olarak değerlendirmekte ve dijital sermaye nitelemesinde

99 el-Akîl, s. 42.

100 Mudârabe, sermaye - emek ortaklığını ifade etmektedir ki zarar sermayeye ait iken karda ortaklık esastır. Bkz. Fahri Demir, İslam Hukukunda Mülkiyet Hakkı ve Servet Dağılımı, Medikomat, Ankara 1993, s.197.

101 el-Akîl, s. 42-44.

102 Evans, s. 4.

103 Evans, s. 7.

104 Adam, s. 40-41. 
bulunmaktadır. Kripto paraları bir mal olarak görmeyenlere karşı kripto paraların transfer edilebilir ve dijital anlamda da olsa temsil kabiliyetini haiz bir nitelik arz ettiğini ileri sürmektedirler. Kripto paralar ticarette kullanılabilir. Bununla beraber kripto paraların para birimi olarak kabul edilebilmesi için değerinin bağımsız bir standarda ve hesap birimine sahip olması gerekmektedir. Kripto paraların bağımsız bir ölçülebilir değeri olmadığından aksine fiyatın kripto paraya değer biçtiğinden, böylece ortaya çıkan belirsizlikten ötürü istikrar vasfını yitiren kripto paralar para birimi olarak değerlendirilmemektedir. ${ }^{105} \mathrm{Bu}$ düşünceye göre paraların bir mal ve takavvuma (kanuni kıymet) sahip olduğu, dolayısıyla yatırıma müsait bir enstrüman şeklinde nitelenebileceği düşünülse de, bir para birimi olarak vasıflandırıması mümkün görünmemektedir. Kripto paraları İslam iktisadına uygun bulmayanlar bile gelecekte kripto paraların yaygınlaşması ve genel kabul görme intimalini dikkate alarak düzenleme, istikrar ve makul bir çerçeveye oturtulması halinde farklı yaklaşılabileceğini ifade etmektedir. ${ }^{106}$

\section{SONUÇ}

İslam dininin ve hukuk sisteminin temel kaynakları Kur'ân-ı Kerîm ve Sünnet-i Nebî, hukuk sistemine benzer biçimde, İslam'ın iktisada yaklaşımına zemin teşkil etmektedir. Ayet-i kerime ve hadis-i şeriflerde para-iktisat teorilerine ilişkin sistematik hukuk normları -tabii olarak- bulunmamakta; borçlanma ayeti gibi istisnai bazı konuları ayrı tutacak olursak, başta faiz, garar yasağı ve diğer haksız kazanç yollarının engellenmesi gibi iktisadi- ticari hayata dair ve adaletin tesisine yönelik genel düzenlemelere gidildiği görülmektedir. ${ }^{107}$ Bu meyanda anılan temel kaynakların bir şeyin para olarak kabul edilebilmesine dair somut, tafsilatlı bir değerlendirmesi görülmemektedir. Zaten bu husus naslarla sabit olması beklenecek bir konu da değildir. Buna göre şekil, madde, isimden ziyade paranın asıl fonksiyonlarını gerçekleştiren ve İslam'ın meşruiyet anlayışına uygun her şeyin para olduğunu belirtmek mümkündür. ${ }^{108}$ Dolayısıyla tarihte insanoğlunun madeni para sistemini aşıp kağıt para sitemine geçtiği gibi, para fonksiyonlarını icra eden yeni sistemleri de eskilerinin yerine ikame etmeye devam etmesi

\footnotetext{
105 Adam, s. 41 ve 49.

106 Adam, s. 43 ve 45.

107 Örneğin faiz yasağı ve alışveriş serbestisi için bkz. Bakara Suresi, 2: 275; haksız kazanç ve aldatma yasağı için bkz. Nisâ Suresi, 4: 29.

108 Gözübenli, “íslam Hukuk Literatüründe Para”, s. 95-96 ve 85-86; Altan, s. 126.
} 
mukadderdir. Nitekim her geçen gün teknolojik gelişmeler ve ihtiyaçlara bağlı olarak ekonomik hayatımıza yeni para veya ödeme, transfer, tasarruf enstrümanları girmektedir. Örneğin yakın geçmişte kredi kartı kullanma konusunda derin, yoğun tartışmaların yapıldığını hatırlamaktayız. Bu açıdan ekonomiyle ilgili kavram tartışmalarının herhangi bir biçimde noktalanacağını ön görmek mümkün değildir.

Kanaatimizce kripto para sistemine dair yapılan yorumların çoğunda "bitcoin" merkezli değerlendirmelerde bulunulması büyük bir eksikliktir. Yukarıda da vurguladığımız gibi bitcoin belki en popüleridir ama bin dört yüze yakın kripto para çeşidinden sadece biridir. Dolayısıyla pek çok avantajı da bulunması dışında bitcoinin İslam hukuku bağlamında menfi niteliklerinin, kripto paraların tümünü ve sistemini haram saymak için genel bir yargıya zemin teşkil ettiğini düşünmek doğru değildir. Özellikle de kripto paraların bir devlet ya da otoritenin güvencesi altında olmadığı iddiası temelinde yükselen gayri meşruluk yargısı bu nedenle çok sayıda kripto para çeşidinde karşıı bulmamaktadır. Rusya'nın Ethriumu, Venezuela'nın Petro'su bu konuda örnek olarak karşımıza durmaktadır. Faraza bir gün Türkiye'nin bor gibi bir madene endeksli devlet kripto parasını (mesela borcoin/borpara) tedavüle sokmayı düşünmesi tümüyle ihtimal dışı bırakılmamalıdır.

Kripto paraların bilhassa küçük tasarruf sahiplerinin dolandııılmasına fırsat veren, çeşitli mağduriyetlere sebebiyet verme riski bulunan ve güvenilirlik açığı içeren bir yönü bulunmaktadır. Bu ve benzeri nedenlere bağlı olarak verilen haram fetvalarının gerçeklik ve doğruluk değeri elbette göz ardı edilemez. Ancak bu para sisteminin, aslında bertarafı veya ıslah edilebilecek menfi yönlerinden dolayı yok farz edilmesi veya değişmez bir gayri meşruluğa mahkum edilmesi, adeta akıntıya karşı kürek çeken bir yaklaşımdır. Mevcut sistemlere nazaran İslam hukukunun ruhuna daha uygun vasıf veya vaatlerinin de bulunduğu dikkate alınarak kripto para sisteminin meşruiyet zemininde nasıl geliştirileceğine dair çalışmalara hızla ağırlık verilmesi elzemdir. Sistemin genel kabul gördüğü, maalesef yine uluslararası tekellerin eline düştüğü; faiz, garar gibi İslam iktisat teorisinin kırmızı çizgilerinin içine bulaştırıldığı bir geleceği yaşamak zorunda kalmadan, yani iş işten geçmeden, İslam'ın bu sisteme dair gerçekçi bakış açısının tespiti ve bunun ışığında İslam'ın ruhuna uygun, özgün bir sistemin/sistemlerin inşasına yönelmenin büyük önem taşıdığına inanmaktayız. 


\section{KAYNAKLAR}

ACAR Ali, "İslami Iktisadın Esasları İsimli Kitabın Para ve Faiz Ile Illgili Kısımların Incelenmesi", İslam Hukuku Araştırmaları Dergisi, Sayı XVI.

ADAM Mufti Faraz (2017), Bitcoin: Shariah Compliant? https://afinanceorg.files.wordpress.com/2017/08/research-paperon-bitcoin-mufti-faraz-adam.pdf adresinden 25 Mayıs 2018 tarihinde erişildi.

ADIAN Sam, İslam Iktisat Teorisi ve Toplumsal Mekanizmalar, Hongkong 2016.

el-AKÎL Abdullah b. Muhammed b. Abdülvehhab (2018), el-Ahkâmu'lFıkhiyyetü'l-Muteallika bi'l-Amelâti'l-Elektruniyye, el-Memleketu'IArabiyyetü's-Suûdiyye Vezâretü't-Ta'lîm el-Câmiatü'l-İslâmiyye bi'lMedîneti'l-Münevvere http://iefpedia.com/arab/wpcontent/uploads/2018/01/Bitcoin4.pdf adresinden 25 Mayıs 2018 tarihinde erişildi.

AKGÜNDÜZ Ahmed, Karşılaştırmalı Mecelle-i Ahkâm-ı Adliyye (Mecelle Ta'dilleri ve Gerekçeleri ile Birlikte), Osmanlı Araştırmaları Vakfı, İstanbul 2013.

ALi HAYDAR Hocaefendizade, Dureru'I-Hukkâm Şerhu Mecelleti'l-Ahkâm, Dâru Alemi'I-Kütüb, Beyrut 2003.

ARAZ Yunus, "İslam Hukuku Açısından Menfaat ve Menfaat İçerikli Bazı Tasarruflar", iLTED, Erzurum 2016/2, Sayı 46.

AREN Sadun Aren, İstihdam, Para ve İktisadi Politika, Bilgi Yayınevi, Ankara 1968.

ALLÂM Şevki İbrahim (2017), "Tedâvül Umleti'l-Bitkoin ve Teâmül bihâ"

http://www.dar-alifta.org/ar/ViewFatwa.aspx?sec=fatwa\&ID=14139

adresinden 25 Mayıs 2018 tarihinde erişildi.

ALTAN Mikail, "Faizsiz Bankacııığın Temelleri", İslam Hukuku Araştırmaları Dergisi, Sayı XVI, 2010.

ARAL Namık Zeki, Para Meselesi ve Bretton Woods Konferansı, Alaattin Kral Matbaacilık, Ankara (t.y.).

ATEŞ Ateş, "Bitcoin: Sanal Para ve Vergileme", Vergi Sorunları Dergisi, Yıl 37, Sayı 308, Mayıs 2014.

AYBAKAN Bilal, "Nakit", DIA, 2006.

AYDIN Mehmet Âkif, "Cuâle" Maddesi, TDV İslam Ansiklopedisi, Cilt VIII. 
BAGUS Philipp, "The Quality of Money", The Quarterly Journal of Austrian Economics 12, No 4 (2009).

BOZDOĞANOĞLU Burçin, "Sanal Para Birimi Bitcoin'in Kayıtdışı Ekonomi ile Karapara Faaliyetlerine Etkisi ve Vergilendirilmesi", Mali Hukuk Dergisi, Cilt 10, Sayı 111, Mart 2014.

ÇARKACIOĞLU Abdurrahman (2016), Kripto-Para Bitcoin, s.4-5 http://www.spk.gov.tr/SiteApps/Yayin/YayinGoster/1130 25 Mayıs 2018 tarihinde erişildi.

DAS Amaresh, "Money as a Medium of Exchange: Then and Now: Can Technology be a Facilitator of Exchange?", Global Journal of Management and Business Research: B Economics and Commerce Volume 15, Issue 11, Version 1.0, Year 2015.

DEMiR Fahri, İslam Hukukunda Mülkiyet Hakkı ve Servet Dağılımı, Medikomat, Ankara 1993.

ed-DESSÛKÎ Şemsüddîn eş-Şeyh Muhammed Arafe, Hâşiyetü'd-Dessûkî alâ Şerhi'l-Kebîr, Îsâ el-Bâbî el-Halebî ve Şürakâuh, t.y. y.y., DIB DIN IŞLERI YÜKSEK KURULU KARARI

https://kurul.diyanet.gov.tr/Karar-Mutalaa-Cevap/38212/dijital-kripto-

paralarin-kullaniminin-dini-hukmu-nedir- adresinden 23 Mayıs 2018 tarihinde erişildi.

DURMUŞ Abdullah, "Fıkhî Açıdan Günümüz Para Mübadelesi İşlemleri" (Basılmamış Doktora Tezi), Marmara Üniversitesi Sosyal Bilimler Enstitüsü, İstanbul 2008.

DÜNYA Şevki Ahmed, el-Cuâle ve'I-Istısnâ', el-Benku'I-İslâmî li't-Tenmiye elMa'hedü'l-islâmi li'l-Buhûs ve't-Tedrîb, t.y. y.y.

EBÛ DÂVÛD Süleymân b. Eş'âs, Sunen, Dâru Sahnûn-Çağrı Yayınları, İstanbul 1992.

ECB European Central Bank, Virtual Currency Schemes - A Further Analysis, Frankfurt 2015.

https://www.ecb.europa.eu/pub/pdf/other/virtualcurrencyscheme sen.pdf adresinden 20 Mayıs 2018'de erişildi.

EGE Börteçin, "Sanal Dünyanın Gerçek Parası: Bitcoin", Bilim ve Teknik, Kasım 2013.

ERKAL Mehmet, İslam'ın Erken Döneminde Vergi Hukuku Uygulamaları, Türkiye Diyanet Vakfı Yay., Ankara 2009. 
ERDEM Ekrem, "Osmanlı Para Sistemi ve Tağşiş Politikası: Dönemsel Bir Analiz", Bankacılar Dergisi, Sayı 56, 2006.

ERDOĞAN Mehmet, Fıkıh ve Hukuk Terimleri Sözlüğü, İstanbul 2010.

ERGIN Feridun, Para ve Faiz Teorileri, Beta Yayım Dağıtım, İstanbul 1983.

Para Siyaseti, Hamle Mat., İstanbul 1966.

ESKicioĞLU Osman, "i̇slam'da Ekonomik Sistem”, İslam Hukuku Araştırmaları Dergisi, Sayı 16, 2010.

EVANS Charles W., "Bitcoin in Islamic Banking and Finance", Journal of Islamic Banking and Finance, June 2015, Volum 3, No 1.

GÖZÜBENLi Beşir, "İslam Hukuk Literatüründe Para”, Para Faiz ve İslam, Çınar Matbaası, İstanbul 2015.

"Semen" Maddesi, TDV İslam Ansiklopedisi, XXXVI.

el-HASENî Ahmed, İslam'da Para, Çeviren Adem Esen, İz Yayıncılık, İstanbul 1996.

Hiç Mükremin, Para, Kredi ve Fiyatlar, Atatürk Üniversitesi Basımevi, Erzurum 1971.

IBN KUDÂME Muvaffakuddîn Ebû Muhammed Abdullah b. Ahmed Muhammed el-Makdisî, el-Mukni' fî Fıkhi'l-Imâm Ahmed b. Hanbel eş-Şeybânî, Mektebetü's-Sevâdey, Cidde 1421/ 2000.

IBN ÂBiDîN Muhammed Emin, Reddü'I-Muhtâr ale'd-Dürri'l-Muhtâr, Dâru Âlemi'l-Kütüb, Riyad 2003.

IBN MÂCE Ebû Abdullah Muhammed b. Yezîd, Sunen, Dâru Sahnûn-Çağrı Yayınları, İstanbul 1992.

KARAMAN Hayrettin (2017), "Sanal para (bitcoin, bitpara)" https://www.yenisafak.com/yazarlar/hayrettinkaraman/sanal-parabitcoin-bitpara-2041314 15 Mayıs 2018 tarihinde erişildi.

KELEŞ Ali, İslam’a Göre Para Kavramı, Doktora Tezi (Uludağ Üniversitesi), Bursa 1998.

KEYDER Nur, Para: Teori, Politika, Uygulama, Bizim Büro Yay., Ankara 1993.

KiSBET Mustafa, "islam Hukukuna Göre Satılan Malın Kabzı ve Hükümleri", İslam Hukuku Araştırmaları Dergisi, Sayı XVI, 2010.

LO Stephanie- Christina Wang, "Bitcoin is a Money", Current Policy Perspectives, Federal Reserve Bank of Boston, 14-4

MÂLiK Muvatta', (Kitâbu'I-Akdiye, Bâbu'I-Kadâ), Hadis No 1461. 
MAURER Bill (2006), "The Anthropology of Money"

http://www.anthro.uci.edu/ wmmaurer/bio/Maurer-AR.pdf 20 Nisan 2018 tarihinde erişildi.

MÜSLiM Ebû'I-Huseyn b. el-Haccâc, el-Câmiu's-Sahîh, Dâru Sahnûn-ÇağrıYay., İstanbul 1992.

ORHAN Osman- Seyfettin Erdoğan, Para Politikası, Avcı Ofset, İstanbul 2002.

ORMAN Sabri, "Modern İktisat Literatüründe Para Kredi ve Faiz", Para Faiz ve İslam, Çınar Matbaası, İstanbul 2015.

ÖZGÜVEN Ali, İktisat Bilimine Giriş, Filiz Kitabevi, İstanbul 1989.

ÖZTÜRK Mustafa, "Genel Hatlarıyla Osmanlı Para Tarihi", Türkler, Yeni Türkiye Yay., Ankara, 2002.

ÖZTÜRK Nurettin- Asuman Koç, "Elektronik Para, Diğer Para Türleriyle Karşılaştırılması ve Olası Etkileri", SÜ iiBF Sosyal ve Ekonomik Araştırmalar Dergisi, XI, 2013.

ÖZYETGiN Melek, “Eski Türklerde Ödeme Araçları, Kağıt para Çav'ın Kullanımı", Modern Türklük Araştırmaları Dergisi, Cilt 1, Sayı 1, Ankara 2004.

PILKINGTON Marc, Blockchain Technology: Principles and Applications, Research Handbook on Digital Transformations, 2016.

NAKAMOTO Satoshi, "Bitcoin: A Peer-to-Peer Electronic Cash System"

http://www.bitcoin.org/bitcoin.pdf adresinden 20 Nisan 2018 tarihinde erişildi.

es-SERAHSî Şemsüddîn, el-Mebsût, Dâru'I-Ma'rife, Beyrut t.y.

SERIN Zehra Vildan, Para Politikası, Marmara Üniversitesi Yay., İstanbul 1987. eş-ŞîRÂZî Ebû İshâk ibrâhim b. Ali b. Yûsuf, el-Mühezzeb fî Fıkhi'l-İmam eşŞâfiî, Dârü'l-Ma'rife, Beyrut 2003.

THORNTON Daniel L. (2000) "Money in a Theory of Exchange" https://files.stlouisfed.org/files/htdocs/publications/review/00/01/ 0001dt.pdf adresinden 20 Nisan 2018 tarihinde erişildi.

et-TiRMizî Ebû Îsâ Muhammed b. Îsâ b. Sevra, Sunen, Dâru Sahnûn-Çağrı Yayınları, İstanbul 1992.

et-TÛsî Ebû Ca'fer Muhammed b. el-Hasen b. Ali, el-Mebsût fî Fıkhi'lİmâmiyye, el-Mektebetü'l-Murtadaviyye, Tahran t.y. 
USLU Rıfat, "islam Hukukunda Para Birimleri", İslami Araştırmalar Dergisi, XXV-I, 2014.

VON MISES Ludwig, The Theory of Money and Credit, Ingilizceye Çev. H. E. Batson, Yale University Press, y.y. 1953.

UZUNÇARŞıLı İsmail Hakkı, Osmanlı Devleti'nde Saray Teşkilatı, Türk Tarih Kurumu Basımevi Yayınları, Ankara 1945

YANARDAĞ M. Özgür, "19. Yüzyıl Osmanlı Devleti Para Düzeni: Kâğıt Para Düzenine Geçiş Aşamalarının Iktisadi Analizi", Uluslararası Sosyal Araştırmalar Dergisi, Cilt 8, Sayı 36, 2015

YÜKSEL Armağan - Ebru Bozkurt, "Elektronik Para, Sanal Para, Bitcoin ve Linden Doları'na Hukuki Bir Bakış", İstanbul Üniversitesi Hukuk Fakültesi Mecmuası, Cilt 73, Sayı 2, İstanbul 2015. 